\title{
The Historical Dimension of the US Dodd-Frank Bill and its Implications to the Financial Governance Reform in Emerging Markets
}

\author{
Wenzhong Zhu', Shen Rui ${ }^{2}$ \\ ${ }^{1}$ Professor of SEIB and researcher of Research Center of International Trade and Economics, Guangdong University of Foreign \\ Studies, Guangzhou 510410, China; ${ }^{2}$ Postgraduate student of SEIB, Guangdong University of Foreign Studies, Guangzhou 510410, \\ China. \\ Email: Wenzhong8988@sina.com
}

Received July, 2013

\begin{abstract}
After about three years of the sub-prime mortgage crisis, the American Congress passed its new financial supervision bill on July 15, 2010, which is called Dodd-Frank Wall Street Reform and Consumer Protection Act. This act was then singed to be in effect by President Obama on July 21. This act is named as the most serious financial supervision act passed ever since the Great Depression in 1933. This paper systematically reviews and analyzes the background, major content, effect, and historical dimension of the bill, and on this basis, it presents some implications to the financial governance reform in emerging markets, such as the maintenance of a proper level of financial deregulation, the protection of interests of financial product consumers, the cultivation of ethical value and social responsibility of financial executives or government leaders, etc.
\end{abstract}

Keywords: Dodd-Frank Bill; Historical Dimension; Implication; Governance; Emerging Market

\section{Introduction}

In 2007, the subprime mortgage in the US triggered the breakout of the global financial crisis which has not been over even today. In 2009, to respond to the crisis, many countries had taken measures of monetary and fiscal policy to recover their economy. China has taken the lead to recover, but facing the new round of inflation, while USA and EU are still in trouble of recovery and recession.

With a multi-dimension mode of financial supervision and control, USA has taken measures from three aspects including financial supervision law and regulation, monetary policy system and fiscal policy system (Figure 1). After the financial crisis, USA has already taken both monetary policy measures such as open market policy operation, etc., and fiscal policy measures such as increasing investment on infrastructure, etc., to respond to it, and these measures have brought some negative effects on the recovery of the US economy. But tracing back to the history, the ultimate root of this crisis is the deregulation of financial supervision starting from 1970s. Therefore, it is necessary for USA to revise its law of financial supervision so as to prevent the re-happening of financial crisis.
In order to avoid the re-happening of similar financial crisis, the US government launched the new financial supervision bill. In 2000, Chris Dodd, Chairman of Senate Financial Services Committee, and Barney Frank, chairman of House Financial Services Committee, recommended the revision of the financial supervision bill. The draft of the bill was then revised in May, 2010, and the revised bill was voted to pass by both Senate and House in June, 2010. On July 21, 2010, the US president signed and the bill came into effect, which is named as the Dodd-Frank Bill.

This paper will discusses the content and influence of the New US Financial Supervision Bill from a historical dimension in order to propose some implications for the financial supervision reform of emerging economies.

\section{Content of the Dodd-Frank Bill}

The aim of issuing the Dodd-Frank Bill is to increase the transparency and responsibility of the US banking and financial system, and to end the "too big to fail" problem of financial institutions so as to prevent the re-happening of financial crisis. This bill contains the 16 provisions such as Financial stability, Regulated clearing, Supervision power transfer to Currency Committee, FDIC and 
Fed, Regulating the advisors of hedge fund investment, etc. The content of the Dodd-Frank Bill can be summarized with the following characteristics: the protection of consumer interests from fraud or risky trap financial services, the avoidance of the problem of financial institutions' "too big to fall", the reform of financial supervision regulation to prohibit financial institutions from conducting transactions which may be in breach from the demand of customers, the strengthened management of financial derivatives' transactions, the strengthened management of mortgage loans, and the perfection of executive compensation system and corporate governance of financial institutions, and others.

\section{Historical Dimension Analysis of the Dodd-Frank Bill}

The Dodd-Frank Bill is seen with historical importance from the over 100-year American financial supervision regulation history. Its core significance sees the US reentry into the era of financial re-regulation from deregulation. The first US Banking Law came into being in 1863, and ever since then the development history of the US financial supervision reform has been nearly 150 years.

From the Table 1, it can be seen that in the past nearly 150 years, especially since 1933 great depression, the US has adjusted, revised or reformed its financial

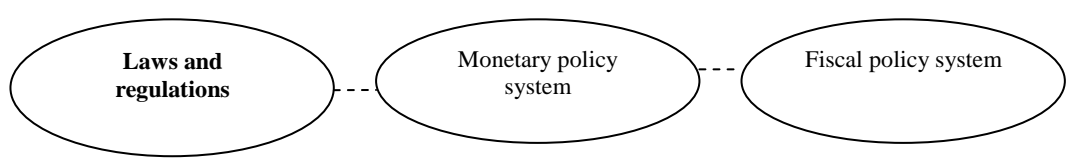

Figure 1. The three dimensions of the US financial supervision system.

Table 1. The Main US financial supervision acts in the history and their main provisions.

\begin{tabular}{|c|c|c|c|}
\hline Time & Bill Name & Background & Main provisions \\
\hline 1863 & National Banking Act & $\begin{array}{l}\text { In the period of US Civil War } \\
\text { needing funds }\end{array}$ & $\begin{array}{l}\text { Establish the Office of the Comptroller of the Currency } \\
\text { to approve and control the national bank }\end{array}$ \\
\hline 1913 & Federal Reserve Act & $\begin{array}{l}\text { In the period of dynamic financial } \\
\text { environment and increasing financial risk }\end{array}$ & $\begin{array}{l}\text { Establish Fed, offer rescues to banks, and control } \\
\text { money supply }\end{array}$ \\
\hline 1933 & Glass Steagall Act & In the period of great depression & $\begin{array}{l}\text { Establish FDIC, and require banks to conduct } \\
\text { separate-business operation }\end{array}$ \\
\hline 1968- & CSR Acts & $\begin{array}{l}\text { Having discrimination in banking } \\
\text { services }\end{array}$ & $\begin{array}{l}1968 \text { Act aims to protect borrowers’ right to be informed; } \\
1974 \text { Act aims to remove sex, age, racial discrimination in } \\
\text { banking services; } 1977 \text { Act aims to remove discrimination } \\
\text { against living places in banking services, etc. }\end{array}$ \\
\hline 1980 & $\begin{array}{l}\text { Depository Institution } \\
\text { Deregulation and Monetary } \\
\text { Control Act }\end{array}$ & $\begin{array}{l}\text { Increased competition in taking deposits, } \\
\text { and challenges of non-interest-bearing } \\
\text { check account deposits }\end{array}$ & $\begin{array}{l}\text { The first deregulation act was passed to allow current } \\
\text { deposits to pay interests }\end{array}$ \\
\hline 1983 & Garn-St. Germain Act & $\begin{array}{l}\text { In the driving force of further } \\
\text { deregulation }\end{array}$ & $\begin{array}{l}\text { Establish money market deposit accounts, and allow the } \\
\text { merger of cross-state banks }\end{array}$ \\
\hline 1987 & $\begin{array}{l}\text { Competitive Equality in } \\
\text { Banking Act }\end{array}$ & $\begin{array}{l}\text { Facing more and more bankrupt cases } \\
\text { of banks and financial institutions }\end{array}$ & $\begin{array}{l}\text { Allow FDIC to establish bridge banks taking over the } \\
\text { bankrupt banks }\end{array}$ \\
\hline 1994 & $\begin{array}{l}\text { The Riegle-Neal Interstate Banking } \\
\text { and Branching Efficiency Act }\end{array}$ & $\begin{array}{l}\text { Stronger and stronger customer demands } \\
\text { for convenient cross-state financial services }\end{array}$ & $\begin{array}{l}\text { Permit bank-holding companies to acquire banks across } \\
\text { states and conduct cross-state businesses }\end{array}$ \\
\hline 1999 & Gramm-Leach-Bliley Act & $\begin{array}{l}\text { In the strong request for banks' } \\
\text { "mixed-business operation” and } \\
\text { further deregulation }\end{array}$ & $\begin{array}{l}\text { Allow bank-holding insurance companies and securities } \\
\text { firms to offer diversified financial services in order to } \\
\text { reduce risks }\end{array}$ \\
\hline 2001 & USA PATRIOT Act & In the danger of terrorism attack & $\begin{array}{l}\text { Require financial institutions to establish customer } \\
\text { identity, and check and report doubtful accounts to the } \\
\text { government }\end{array}$ \\
\hline 2003 & $\begin{array}{l}\text { Fair and Accurate Credit } \\
\text { Transactions Act }\end{array}$ & $\begin{array}{l}\text { In the danger of more and more theft } \\
\text { cases of customer identity }\end{array}$ & $\begin{array}{l}\text { Enable each customer to receive at least one free credit } \\
\text { report, and require the federal trade committee to } \\
\text { facilitate the reporting of sufferers }\end{array}$ \\
\hline 2010 & The Dodd-Frank Bill & $\begin{array}{l}\text { In the period of subprime mortgage crisis and } \\
\text { ongoing global financial crisis }\end{array}$ & $\begin{array}{l}\text { Increase the transparency and responsibility of financial } \\
\text { system to protect the interest of consumers, and strengthen } \\
\text { the control on big financial institutions to prevent new } \\
\text { financial crises }\end{array}$ \\
\hline
\end{tabular}


supervision regulations in response to the change of government, society, market, and financial environment, and especially the happening of some historic events.

At the same time, these series of financial supervision laws and regulations in the history are made as institutional tools of financial governance reform to timely regulate or deregulate the financial market, which have brought subsequent influences on the development of financial market stability and national economy. But, of course, if a deregulation act or financial governance reform policy is not properly treated or handled, it may lead to the financial or economic crisis of the country or the whole world.

From the historical dimension of the US financial governance reforms, it can be clearly seen that before the 1930s, the US was over deregulated in the financial market, making it possible for commercial banks to conduct mixed-business operation, as result, the Great depression occurred, which brought the first big disaster to the world economy. After the economic crisis, the US Congress passed the Glass Steagall Act in 1933 to require commercial banks and investment banks to conduct separate-business operation. The financial governance reform from deregulation to regulation had maintained the stability of the US economy from 1930s to 1980s.

However, in the late 1970s and the early 1980s, as a result of pressure of financial market competition, especially from the non-bank financial institution, the US passed the first act of financial deregulation, namely the Depository Institution Deregulation and Monetary Control Act of 1980, to allow current deposits to pay interests to customers and open fixed transaction accounts. A further step of deregulation was achieved in 1993, when the Riegle-Neal Interstate Banking and Branching Efficiency Act was passed to permit bank-holding companies to acquire banks across states and conduct cross-state businesses, and in 1999 when Gramm-Leach-Bliley Act was passed to allow bank-holding insurance companies and securities firms to offer diversified financial services, and in this period, the real sense of mixed-business operation of financial institutions was once again in effect. Till 2007, the financial deregulation had led to the innovation of financial products such as the popularity of the so-called financial derivative products and the loosened lending policy of subprime mortgage facility, which had resulted in the breaking of the recent global financial crisis.

Today, this global financial crisis triggered by the US subprime mortgage crisis has not come into a complete end. The Dodd-Frank Bill passed 1n 2010 has started the new round of financial re-regulation.

\section{Implications to the Financial Governance Reform in Emerging Markets}

Historically, the Dodd-Frank Bill implies a new era of
American financial governance reform, or a new beginning of another round of financial stability with the protection of this financial re-regulation act.

Emerging markets such as the BRIC nations are now generally imperfect in their financial supervision mechanism or governance system although their economic performances are currently all much better than those of the developed nations. Emerging markets are now facing even more challenges of potential financial crisis as they are realizing financial or economic globalization. Therefore, emerging markets are suggested to learn some lessons from the historical dimension analysis of the DoddFrank Bill.

First, the historical dimension analysis of the DoddFrank Bill indicates that the maintenance of a proper level of financial deregulation is the key to avoiding or preventing a new financial crisis. Therefore, the direction of financial governance reform in emerging markets should target at the achievement of an appropriately tight or loose financial regulation policy.

Second, the timely adjustment or revision of financial supervision laws or regulations in accordance to a specific economic circumstance is essential to the stability of a financial market or economy. Therefore, emerging markets which are usually not perfect in their institutional construction of financial governance or supervision should learn to timely make or revise corresponding financial supervision regulations in order to timely solve some important economic problems which have arisen in the nation.

Third, the real protection of interests of financial product consumers is the ultimate goal of all financial supervision acts, as can be seen from all the American supervision acts such as FDIC Improvement Act, CSR Act, and the Dodd-Frank Bill. Therefore, emerging markets are suggested to reform their financial governance system with their first priority given to the interest protection of financial product consumers.

Forth, the enhanced scope of financial supervision on large financial institutions in a financial market is of great importance to the prevention of financial crisis. Therefore, emerging markets should attach great importance to the construction of a more strict control and supervision system on their big banks or other financial institutions in their financial market when they conduct financial governance reforms.

Fifth, the cooperative or integrated role of a three-dimension financial supervision system is the key to guarantee the high efficiency of financial supervision. Emerging markets are suggested to handle financial and economic problems by means of integrating or coordinating the three financial governance systems including financial supervision laws, monetary policy tools and 
fiscal policy tools.

In addition, the international cooperation of different countries as an institutional arrangement is necessary to the successful guarantee of a singe nation's or the world's economic stability and development. The last but not the least, the cultivation of ethical value and social responsibility of financial executives or government leaders is extremely important for the prevention of any financial crisis.

\section{REFERENCES}

[1] "Bill Summary \& Status - 111th Congress (20092010)-H.R.4173-All Information-THOMAS (Library of Congress)". Library of Congress.

http://thomas.loc.gov/cgi-bin/bdquery/z?d111:HR04173: @@@L\&summ2=m\&\#major\%20actions. Retrieved July 22, 2010.

[2] "Dodd-Frank Wall Street Reform and Consumer Protection Act"-from Wikipedia, the Free Encyclopedia.http://en.wikipedia.org/wiki/Dodd\%E2\%80 \%93Frank_Wall_Street_Reform_and_Consumer_Protecti on_Act. Retrieved October 5, 2010.

[3] "Obama to Sign Dodd-Frank Financial Regulatory Reform Bill Into Law Today,” The Washington Independent.
July 21, 2010.

http://washingtonindependent.com/92161/obama-to-signdodd-frank-financial-regulatory-reform-bill-into-law-toda y. Retrieved October 5, 2010.

[4] Peter S. Rose \& Sylvia C. Hudgins, Bank Management \& Financial Services. 7th edition and the English-Chinese bilingual edition. McGraw-Hill Education (Asia) Co and China Machine Press, 2007, pp. 31-62.

[5] Blair, E. Christine and R. M. Kushmeider, "Challenges of the Dual Banking System: The Funding of Bank Supervision,” FDIC Banking Review, Vol. 18, No. 1. 2006, pp. 1-21.

[6] Comptroller of the Currency. Comptroller's Licensing Manual. Washington D.C., January, 2005

[7] X. Q. Wu, On the Handling of “Too Big to Fall” Problem from the US Financial Supervision Reform. China Finance, 2010- 16.

[8] W. W. Ying, The US Financial Supervision Reform Act and its Effect on the Global Financial Market. Accountant, 2010-8.

[9] W. Z. Zhu, On the Criteria and Mechanism for Commercial Banks’ CSR. Economic Management Press, 2009.

[10] L. Z. Son, et al., The Explanation of US Dodd-Frank Bill: Lessons and Implications for our Country's Financial Supervision. Macro Economy Research, 2011-1. 